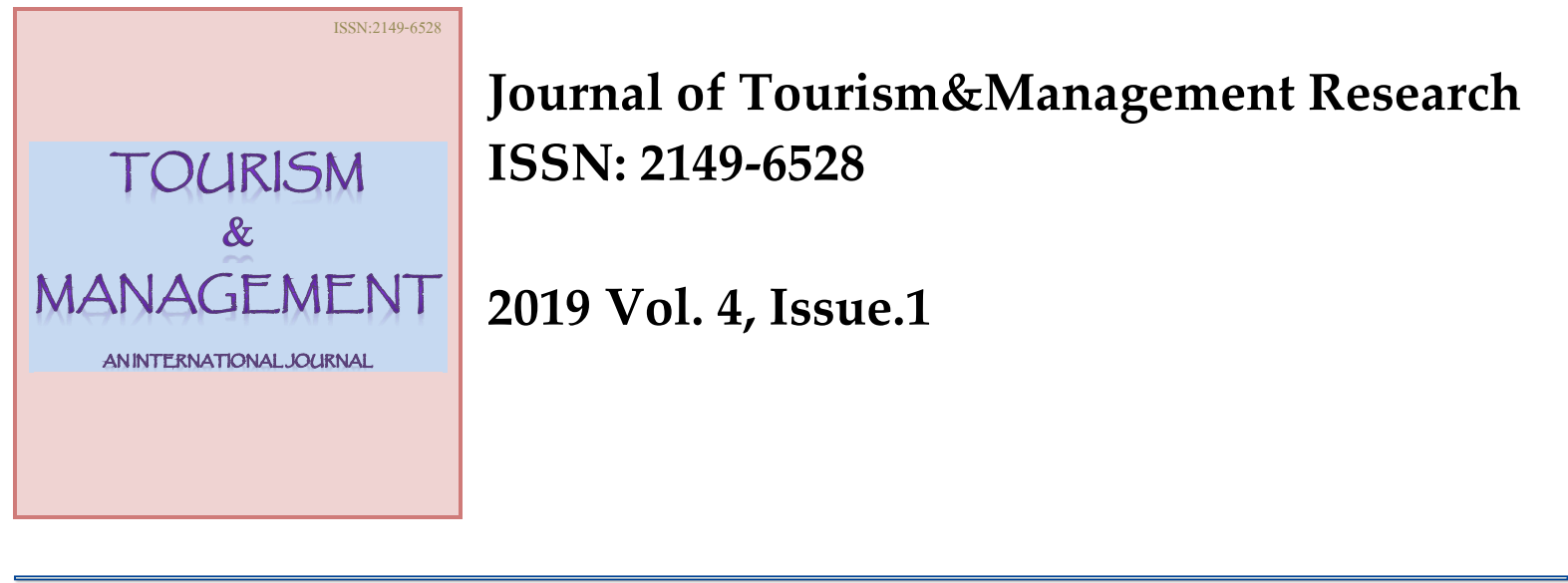

\title{
Bibliometric Analysis of Published Postgraduate Dissertations About Clustering Within the Scope of Regional Development (2006-2017): An Evaluation from Tourism Perspective
}

\begin{abstract}
The aim of this study is to investigate the postgraduate dissertations, related with 'clustering in regional development' by a bibliometric analysis within the scope of certain parameters, which were written between the years 2006 to 2017 and partially or totally open access on the official website of the Higher Education Council, Turkey. Depending on the objectives of the research, the total number of 66 masters and $\mathrm{PhD}$ dissertations were evaluated. These evaluated postgraduate dissertations were analyzed by the bibliometric characteristics like 'distribution by years', 'type of the postgraduate dissertations', 'institutions of postgraduate education', 'institute of released dissertations', 'department of released dissertation', 'key words of released dissertations'. It is displayed by the findings that the most postgraduate dissertations were written between the years 2013 and 2015. Dissertations about clustering within the scope of regional development vary both by subject and department. It is determined that business management, economy, urban and rural planning, tourism, geography and finance were the most frequent subjects in the clustering-based dissertations. The study concluded that $\mathrm{PhD}$ dissertations about clustering within the concept of regional development were more than Master dissertations. The studies analyzed about tourism clusters indicated that the provinces Antalya, Erzurum, İstanbul, İzmir and Nevşehir were studied within this concept.
\end{abstract}

Keywords: Clustering, Regional development, Postgraduate dissertation, Bibliometric analysis, Tourism.

JEL Classifications: R58; F63; Z32; Y4

Submitted: 21.11.2018; Accepted: 25.02.2019

Gencay Saatci, Assistant Professor (Corresponding Author). Çanakkale Onsekiz Mart University

Tourism Faculty, Department of Accommodation Management, Çanakkale-Turkey. +90 2862180546

Email: gencaysaatci@comu.edu.tr

Tarık Yalcinkaya, Research Assistant. Çanakkale Onsekiz Mart University, Institute of Social

Sciences, Çanakkale-Turkey. +90 2862180546.

Email: tarikyalcinkaya@windowslive.com 


\section{Introduction}

Economic development is essential for countries and regions. It affects the social, political and cultural life deeply and strongly. Human movements would be restricted without economic development. Regional development is regarded as an opportunity for countries to close the economic gap between their undeveloped regions and developed ones. There has been an ongoing interest in regional development for the last decades. Because, through advantages of regional development, the awareness of competitiveness and sustainability can be increased in the region, especially among the companies. Additionally, more job opportunities can be provided for the inhabitants which leads to economic development. Also interregional economic differences can be observed almost in all countries although their dimensions vary across countries. Governments, for this reason, have set off a quest for closing these gaps and maintaining sustainable economic development and having a balanced growth. Regional development is a process where all types of regional and local actors involved such as local authorities, universities, research centers, small and medium-sized enterprises (SMEs) and other related companies.

Being one of the most efficient policy tools within the scope of regional development, clustering approach serves for the similar purposes. Clustering, defined by Porter (1998) as geographical concentrations of interconnected companies, specialized suppliers, service providers, firms in related industries, and associated institutions (for example universities, standards agencies and trade associations) that not only compete but also co-operate with the regions by providing a variety of advantages. By cooperation in clusters, companies could lower their costs, meet their need for personnel, or increase their capacity. A cluster is a network of companies, their customers and suppliers of all the relevant factors, including materials and components, equipment, training, finance and so on. It extends to educational establishment and research institutes which provide a large part of their human and technologic capital (Kachniewska, 2013). Bathelt et al. (2004) suggest that while much of the literature about clustering focuses on network relations between firms, it is more important to start out by considering the learning process that takes place within the firm before turning to the role of interfirm interaction. This can be carried out by learning organizations. Having stronger communication network through clustering, managers may be more able to reach information faster and use it on time to take action in their companies. Clustering is a longrunning process of which each phase requires profound preparation. For this reason, regions willing to improve their competitiveness need to lead clustering process with a proper strategic planning. Isbasoiu (2006) stated that "best practice suggests that cities and regions are seeking to build industrial clusters, as they provide fertile ground for innovations, competitiveness economies of scale, rapid rates of technology transfer and efficiencies through resource leveraging." Meaning "working together", the concept "cluster" is made of companies, educational centers and local authorities. The collaboration of these actors maintains the sustainable economic development and competitiveness both of region and companies.

After having analyzed the related literature, it has been observed that there are bibliometric studies in several science fields and disciplines, however none of them was related clustering. Therefore, in order to meet the need, postgraduate dissertations have been analyzed in terms of clustering. The term clustering has been analyzed for the first time with a bibliometric method and this contributes a lot to the authenticity of the study. Against this backdrop, the current study aims to investigate the postgraduate dissertations, related with 'clustering in regional development' by a bibliometric analysis within the scope of certain parameters, which were written between the years 2006 to 2017 and partially or totally open access on the official website of the Higher Education Council, Turkey. 


\section{Literature Review}

As the years goes by and technology improves, the economic behaviors of people and countries change accordingly. Governments noticed the importance of regional development, especially during the World Wars. Regional development is a strategical way whereby the undeveloped regions can keep up with the developed ones and the developing ones can take the advantage using their own potentials. Massey (1995) defines regional development as "interrelated processes" just as Amin and Thrift (2002) describes it as "series of related processes". Çeken (2008) sees the regional development as "an increase in welfare level of a region". Özyücel (2008) regards the concept "regional development" as a process in which the economy of less developed regions in a country is improved and their regional welfare is increased. The objectives of the regional development can be observed as follows:

- Make up the economic differences among the regions,

- Make up the social differences among the regions,

- Provide employment opportunities,

- Provide environmental sustainability,

- Making long-term development plans,

- Improve competitiveness level of regions,

- Improve infrastructure and superstructure of regions.

When taken the compelling competitiveness into consideration among the companies in industry, it is observable that the survival of companies is steadily getting tougher day by day; therefore, it is unavoidable for companies to collaborate with each other for their sustainable economic development. Clustering is a strategic policy tool for regional development which can be utilized by regions and governments. Regional competitiveness can be developed by clustering approach. Ceglie and Dini (1999) imply that the concept "cluster" is used to state geographical and sectoral allocation of companies which are interrelated and complementary to each other. Porter (1998) defines clustering as geographical centralization of interconnected companies, specialized suppliers, service providers, firms in related industries, and associated institutions (for example universities, standards agencies and trade associations) that compete and co-operate as well. It is defined by Delgado and et al. (2016) as geographic centralization of industries related by knowledge, skills, inputs, demand and/or other linkages. "Clusters are a characteristic phenomenon in local or regional markets, but their function is to build a competitive advantage for cluster members on a larger scale - not only nationally but also internationally" (Manuela and Kristina, 2017). Regional cluster is defined by Glinskiy et al. (2016) as a set of enterprises, centralized and localized in one area, and interrelated economic and production processes.

One of the most fundamental requirements for clustering, as stated in the most of clustering definitions, is geographic centralization which allows cluster companies to create synergy and to cooperate each other in a productive way. Clusters are primarily characterized - besides geographic proximity - by the nature and frequency of interactions between the different actors in presented business area. Clustering is the concept regarded as a geographic proximity group of interconnected companies and related organizations in a certain area (Eisingerich and et al., 2010). Oerlemans and et al. (2001) emphasize the importance of clustering in terms of innovation with the words that clustering approach allows companies to perceive new technological opportunities and buyer needs more clearly.

Companies and institutions in clusters can achieve synergies and improve economic advantages from common access to information and knowledge network, supplier and distribution chains, markets, core competencies and resources. Clustering approach concentrates on linkages and interdependencies among actors in value chain (Enright and Roberts, 2001). It can improve economic development by developing the productivity of 
firms based in an area; by driving the direction and pace of innovation, and by stimulating the formation of new businesses, expanding and strengthening the cluster (Huggins, 2008).

Within a cluster, companies can acquire additional advantages in competitiveness thanks to internal specialization, standardization, minimization of the costs on the introduction of the innovations (Zedgenizova and Ignatyeva, 2017). Clusters founded on innovative forms are the engine of regional innovation development for many reasons. The first of which is that all companies collaborating with each other boost the co-operation. The second one is that rapid and efficient information flow speed up the process of information transfer in addition to logistic process in the cluster. Another reason is that coordination and regional support of cluster activities are required (Albekov et al., 2017). From this point, it may be understood that these companies should be in the same sector; however, cluster is a geographical cooperation of value chains in which companies, public institutions and universities carry out business with each other. These value chains consist of complementary or related companies from different sectors. Companies can meet each other's needs, be each other's suppliers or clients. In this regard, the local authorities, research centers and universities in the cluster have important tasks for the competitiveness of the cluster. Research centers and universities are expected to contribute to the innovation of the companies. They can develop innovative products or services for cluster companies and provide them qualified employee. Universities providing industry-based research and specialized training for cluster companies and local authorities contribute to infrastructure of cluster companies, which enable companies to improve their own investments in innovative activities (Enright and Roberts, 2001). Local authorities, governmental institutions, on the other hand, can act for cluster as a facilitator. They can lead the cluster, solve the financial or other law-related problems. This is stated in a similar way by Iordache et al. (2010) that the clustering of companies is not only natural; governments can also encourage the development of emerging clusters by supporting efforts that a group of companies can do to achieve the full potential merger. This means that the companies within a cluster can come together by themselves or that they can be formed by strategic plans of local authorities.

The goals of clustering approach within the scope of regional development are as follows:

- Increase the competitiveness of the companies and the region,

- Provide companies with qualified employee,

- Lower the costs of the companies by cooperating,

- Finding new markets,

- Improve innovation of companies through universities and research centers,

- Improve core abilities of companies by receiving trainings such as training on foreign trade, human resources training, finance training,

- Increase the attractiveness of the region,

- Increase the sales of companies,

- Maintain the economic and social sustainability of the region,

- Contributing to regional and national economy.

Lagendijk and Charles (1999) summarize that the common goal of clustering approach is to bring different types of companies and institutions together around a unique chain of supply or a common source or technology, thus enhancing economic integration as well as boosting communication and knowledge transfer among companies. Rosenfeld (1997) emphasizes the importance of co-operation, social infrastructure and information flow among the cluster companies. According to him, a cluster is concentration of companies which can create synergy due to their geographic proximity and their interdependencies. Scheer and Zallinger (2007) state that clusters are business network co-operation of many different actors in a production system. Njøs and Jakobsen (2016) underline that industrial clusters are acknowledged as corner stones of economic growth and innovation in the modern world; for 
this reason, they are regarded as building blocks of economic activities carried out by companies, regions or even nations.

Clusters are based on complicated relationships among the partners. These relationships can be founded on common or complementary products/services, production and distribution processes, basic technologies, resource requirement, logistics, education, business and external source services (Matopoulos et al., 2005). The cooperation among cluster members, especially between companies and governmental institutions, is determinant how competitive the cluster can be. They have the ability to facilitate processes and to solve possible problems which companies may face during the foundation period of cluster. The governmental institutions can lead the organization but this leadership should not hinder participation of companies to cluster activities. Ketels (2009) also underlines that if the involvement of government restricts the participation in processing of cluster, it can be harmful for the development of clusters. A similar warning is stated in another paper of Ketels (2009) in which she states that governmental institutions need to participate in cluster activities; nonetheless, they are not expected to act as the leader of the cluster (Ketels and Memedovic, 2008). Iordache et al. (2010) mention that governmental institutions must improve the type interfere networks, especially between foreign direct investment and SMEs in the region for cooperation to create chain of companies with high added value to the economy.

\section{Methodology}

The biographical guide "American Men of Science" starting to be published in 1906 for every five years by Cattell is generally associated with the first systematic statistic in science. In this study, Cattell mentioned two dimensions to measure science: quantity and quality. These two dimensions majorly define the modern-day study field of bibliometric (Jacobs, 2010). Bibliometric have become a standard tool of science policy and research method (Glaenzer, 2018). Bibliometric data, whose variety and amount have been progressively increasing in scientific studies, are utilized to evaluate research performance, especially in nature and life science disciplines. In this sense, bibliometric indicators provide confidential image with scientific activity; for instance, sort and number of publications are regarded as proof of scientific production. Citation-based indicators are acknowledged as a measurement of the impact of research and its international visibility (Rinia et al., 1998). Bibliometric utilizes mathematical and statistical methods in order to measure and analyze efficiency of scientific activities. With help of bibliometric, researchers can analyze characteristics of literature and discipline, sort of materials from scientific researches, relations and links of theory (Jacobs, 2010). By utilizing bibliometric methods, it is possible to determine subject headings in a country in a certain discipline, authors of these subjects, cooperation among authors or how low or high the number of subject headings is in literature (Zan, 2018). Koehler (2001) mentions that those interested in bibliometric can be separated into at least four groups:

- Those focusing on citation analysis for individuals, institutions, countries and disciplines,

- Those focusing on co-citation analysis to map individuals, countries, idea changing, and mentality,

- Those focusing on productivity and impact analysis of individuals, institutions, and countries,

- Those concerned with the book, the article, the patent, and other "knowledge outputs.".

According to information mentioned above, it is an undeniable fact that postgraduate researches are also significant for academic development of a science field (Gökkaya, et al., 2017). The goal of the study is to determine postgraduate dissertations opened access in the official website of the Council of Higher Education between 2006-2017, about clustering 
within scope of regional development by a bibliometric method. For this purpose, bibliometric analysis method was carried out in the study. The analyzed dissertations were collected from the web database of the National Center of Dissertations belonging to the Council of Higher Education. The number of collected postgraduate dissertations with the key Word "clustering" from the internet site is 116 ; however, the dissertations related to regional development were included only in the analysis. Physics engineering, medical biology, back prop networks, neural networks, geodesy and photogrammetry, bioengineering, computer sciences, chemistry, genetics, statistics and fuzzy clustering were left out of the scope. In this respect, 66 dissertations were analyzed and the questions whose answers were searched for are as follows:

- How is the annual distribution of dissertations?

- What are the types of dissertations?

- In which higher education institution is the postgraduate education carried out?

- How is the distribution of dissertations by the affiliated institutions?

- How is the distribution of dissertations by the departments?

- How is the distribution of dissertations by the subjects?

- Are the dissertations accessible or not?

- What are the other additional key words with 'clustering' in the published postgraduate dissertations?

- How is the distribution of dissertations by publishing language?

- What are the research types of dissertations?

- What are the average page range of the published postgraduate dissertations?

- How is the distribution of academic titles of dissertation supervisors?

For searching the answers of the questions mentioned above, data collected from the official website of the Higher Education Council wherein the National Dissertation Center is linked (tez.yok.gov.tr). The research findings were obtained in consequence of searching on the web site mentioned above-between the dates 10.01.2019-16.01.2019.

\section{Results}

The total number of the dissertations about clustering published between the years 2006-2017 is 66 in total. Within the scope of the research, all of them were analyzed. The distribution of published postgraduate dissertations by years is demonstrated in Table 1.

Table 1: The Distribution of Postgraduate Dissertations by Years.

\begin{tabular}{|l|c|c|}
\hline Year & $\boldsymbol{f}$ & $\boldsymbol{\%}$ \\
\hline $\mathbf{2 0 0 6}$ & 1 & 1,52 \\
\hline $\mathbf{2 0 0 7}$ & - & 0,00 \\
\hline $\mathbf{2 0 0 8}$ & 1 & 1,52 \\
\hline $\mathbf{2 0 0 9}$ & 5 & 7,58 \\
\hline $\mathbf{2 0 1 0}$ & 5 & 7,58 \\
\hline $\mathbf{2 0 1 1}$ & 5 & 7,58 \\
\hline $\mathbf{2 0 1 2}$ & 4 & 6,06 \\
\hline $\mathbf{2 0 1 3}$ & 11 & 16,67 \\
\hline $\mathbf{2 0 1 4}$ & 6 & 9,09 \\
\hline $\mathbf{2 0 1 5}$ & 11 & 16,67 \\
\hline $\mathbf{2 0 1 6}$ & 8 & 12,12 \\
\hline $\mathbf{2 0 1 7}$ & 9 & 13,64 \\
\hline Total & $\mathbf{6 6}$ & $\mathbf{1 0 0 , 0 0}$ \\
\hline
\end{tabular}


According to Table 1, 66 postgraduate dissertations were published in total between the years 2006-2017. It can be stated that the published dissertations increased in numbers in 2013 since the number of postgraduate dissertations between 2006-2012 is only 5. The most postgraduate dissertations were published between the years 2013 and 2015. As of 2013, the total number of published postgraduate dissertations about clustering is 45 . Consequently, it is possible to mention that there has been an increasing interest in published postgraduate dissertations in the 2013 and onwards. The distribution of published postgraduate dissertations about clustering by types is demonstrated in Table 2.

Table 2: The Distribution of Postgraduate Dissertations by Types.

\begin{tabular}{|l|c|c|}
\hline The Type of Dissertation & $f$ & $\%$ \\
\hline Master & 30 & 45,45 \\
\hline PHD & 36 & 54,55 \\
\hline Total & $\mathbf{6 6}$ & $\mathbf{1 0 0 , 0 0}$ \\
\hline
\end{tabular}

As observed in Table 2, 30 of the evaluated dissertations are in master and 36 of those are in $\mathrm{PhD}$. The distribution of dissertations about clustering by types is almost equal. In Table 3 below, the institutions in which the authors of the dissertations completed their postgraduate education demonstrated.

Table 3: The Distribution of Universities in which Postgraduate Education is completed.

\begin{tabular}{|l|c|c|l|c|c|}
\hline University & $\boldsymbol{f}$ & $\mathbf{\%}$ & University & $\boldsymbol{f}$ & $\mathbf{\%}$ \\
\hline Abant İzzet Baysal University & 1 & 1,52 & Harp Akademisi University & 1 & 1,52 \\
\hline Adnan Menderes University & 2 & 3,03 & Hasan Kalyoncu University & 1 & 1,52 \\
\hline Afyon Kocatepe University & 1 & 1,52 & İstanbul University & 4 & 6,06 \\
\hline Akdeniz University & 1 & 1,52 & İstanbul Teknik University & 2 & 3,03 \\
\hline Ankara University & 2 & 3,03 & İstanbul Ticaret University & 1 & 1,52 \\
\hline Atatürk University & 2 & 3,03 & Kahramanmaraş Sütçü İmam U. & 1 & 1,52 \\
\hline Bartın University & 2 & 3,03 & KTO Karatay University & 1 & 1,52 \\
\hline Beykent University & 1 & 1,52 & Marmara University & 1 & 1,52 \\
\hline Boğaziçi University & 2 & 3,03 & Mimar Sinan University & 1 & 1,52 \\
\hline Celal Bayar University & 2 & 3,03 & Nevşehir Hacı Bektaş Veli U. & 1 & 1,52 \\
\hline Çukurova University & 3 & 4,55 & Niğde University & 2 & 3,03 \\
\hline Dokuz Eylül University & 5 & 7,58 & Nişantaş1 University & 1 & 1,52 \\
\hline Dumlupınar University & 1 & 1,52 & Okan University & 2 & 3,03 \\
\hline Ege University & 2 & 3,03 & Ortadoğu Teknik University & 2 & 3,03 \\
\hline Erciyes University & 1 & 1,52 & Pamukkale University & 1 & 1,52 \\
\hline Erzurum Teknik University & 1 & 1,52 & Sakarya University & 2 & 3,03 \\
\hline Gazi University & 4 & 6,06 & Selçuk University & 2 & 3,03 \\
\hline Gaziosmanpaşa University & 1 & 1,52 & Süleyman Demirel University & 6 & 9,09 \\
\hline Total & & & $\mathbf{6 6}$ & $\mathbf{1 0 0 , 0 0}$ \\
\hline
\end{tabular}

As demonstrated in Table 3, the most dissertations within the scope of regional development have been written in Süleyman Demirel University, which is 9,09\%. Dokuz Eylül University with $7,58 \%$ is ranked number two . There are two universities in the third place, which are Gazi University (6,06\%) and Istanbul University $(6,06 \%)$. In Table 4, the distribution of the dissertations by institutions is demonstrated. 
Table 4: The Distribution by Affiliated Institute.

\begin{tabular}{|l|c|c|}
\hline Institutions & $\boldsymbol{f}$ & $\mathbf{\%}$ \\
\hline Principles of Atatürk and Revolution History Institute & 1 & 1,52 \\
\hline Institute of Foreign Trade & 1 & 1,52 \\
\hline Institute of Education Sciences & 1 & 1,52 \\
\hline Institute of Natural and Applied Sciences & 12 & 18,18 \\
\hline Institute of Social Sciences & 50 & 75,76 \\
\hline Institute of Strategical Research & 1 & 1,52 \\
\hline Total & $\mathbf{6 6}$ & $\mathbf{1 0 0 , 0 0}$ \\
\hline
\end{tabular}

As demonstrated in Table 4, Institute of Social Sciences with 50 dissertations is in the first place in terms of the distribution of institutions in which the postgraduate dissertations were written. It is followed by Institute of Natural and Applied Sciences with 12 dissertations. In this sense, it is possible to state that clustering within the scope of regional development is a subject of social sciences rather than the other branches. In Table 5, the distribution of dissertations by departments is demonstrated.

Table 5: The Distribution of Dissertations by Departments.

\begin{tabular}{|l|c|c|}
\hline Departments & $\boldsymbol{f}$ & $\mathbf{\%}$ \\
\hline Principles of Atatürk and Revolution & 1 & 1,52 \\
\hline Human and Economic Geography & 1 & 1,52 \\
\hline Science and Technology Policy Studies & 1 & 1,52 \\
\hline Geography & 2 & 3,03 \\
\hline Labor Economics & 1 & 1,52 \\
\hline Industrial Engineering & 1 & 1,52 \\
\hline Physics & 1 & 1,52 \\
\hline Economy & 15 & 22,73 \\
\hline Business Management & 24 & 36,36 \\
\hline Business Education & 1 & 1,52 \\
\hline Finance & 2 & 3,03 \\
\hline Forest Industry Engineering & 1 & 1,52 \\
\hline Marketing & 1 & 1,52 \\
\hline Defense Resources Management & 1 & 1,52 \\
\hline Urban and Regional Planning & 8 & 12,12 \\
\hline Agricultural Economics & 1 & 1,52 \\
\hline Tourism Management & 3 & 4,55 \\
\hline International Trade & 1 & 1,52 \\
\hline Total & $\mathbf{6 6}$ & $\mathbf{1 0 0 , 0 0}$ \\
\hline
\end{tabular}

As demonstrated in Table 5, the postgraduate dissertations about clustering within the scope of regional development were written by 18 different departments. The most written dissertations about clustering within the scope of regional development belong to the Department of Business Management with 36,36\%. It is followed by the Department of Economy with $22,73 \%$, the Department of Urban and Regional Planning with 12,12\% and the Department of Tourism Management with 4,55\% respectively. In Table 6, the distribution of the published postgraduate dissertations about clustering within the scope of regional development by subjects is demonstrated. 
Table 6: The Distribution of Postgraduate Dissertations by Subjects.

\begin{tabular}{|l|c|c|}
\hline Subject & $\boldsymbol{f}$ & $\mathbf{\%}$ \\
\hline Banking & 1 & 1,30 \\
\hline Science and Technology & 1 & 1,30 \\
\hline Geography & 3 & 3,90 \\
\hline Labour Economics and Industrial Relations & 1 & 1,30 \\
\hline Economy & 18 & 23,38 \\
\hline Industry and Industrial Engineering & 1 & 1,30 \\
\hline Physics and Physics Engineering & 1 & 1,30 \\
\hline Hospitals & 1 & 1,30 \\
\hline Medical Institutions Management & 1 & 1,30 \\
\hline Business Management & 29 & 37,66 \\
\hline Finance & 2 & 2,60 \\
\hline Forest and Forest Engineering & 1 & 1,30 \\
\hline Defence and Defence Technologies & 1 & 1,30 \\
\hline Sociology & 1 & 1,30 \\
\hline Urban and Rural Planning & 8 & 10,39 \\
\hline Tourism & 6 & 7,79 \\
\hline Agriculture & 1 & 1,30 \\
\hline Total & $\mathbf{7 7}$ & $\mathbf{1 0 0 , 0 0}$ \\
\hline
\end{tabular}

According to Table 6, 29 of the postgraduate dissertations belong to the subject "Business Management" and 18 of those belong to the subject "Economy. They are followed by the subject "Urban and Rural Planning" with 8 dissertations, the subject "Tourism" with 6 dissertations, the subject "Geography" with 3 dissertations and the subject "Finance" with 2 dissertations respectively. While analyzing the dissertations, all subject headings given by the authors have been taken as a basis. In Table 7, the accessibility status of key words of postgraduate dissertations is demonstrated.

Table 7: Accessibility Status of Key Words.

\begin{tabular}{|l|c|c|}
\hline Accessibility of Key Words & $\boldsymbol{f}$ & $\mathbf{\%}$ \\
\hline Access Granted - unspecified & 9 & 13,64 \\
\hline Access Denied - unspecified & 3 & 4,55 \\
\hline Access Denied - Specified & 1 & 1,52 \\
\hline Access Granted - Specified & 53 & 80,30 \\
\hline Total & $\mathbf{6 6}$ & $\mathbf{1 0 0 , 0 0}$ \\
\hline
\end{tabular}

In Table 7, 66 postgraduate dissertations were analyzed in terms of accessibility status of the dissertations and their key words. In this regard, there are 53 postgraduate accessible dissertations and their key words are also accessible. Although there are 9 postgraduate accessible dissertations, they don't have any key words. Furthermore, there are 3 nonaccessible dissertations whose key words are also non-accessible. There is a non-accessible dissertation whose key words are stated in its abstract. One of the limitations of this research is that the keywords of all dissertations are not accessible. In Table 8, the key words of the dissertations about clustering within the scope of regional development are presented. 
Table 8: The Distribution of Key Words Utilized in Dissertations.

\begin{tabular}{|c|c|c|}
\hline Letter & The Keywords Used & $f$ \\
\hline \multirow{9}{*}{$\mathbf{C}$} & Clustering & 27 \\
\hline & Cluster & 12 \\
\hline & Competitive Advantage & 7 \\
\hline & Competition & 6 \\
\hline & Competitiveness & 5 \\
\hline & Competitive Power & 4 \\
\hline & Cooperation & 3 \\
\hline & Clustering Policy, Clustering Supports, Clustering Analysis, Clustering Model & 2 \\
\hline & $\begin{array}{l}\text { Cancer, City, Culture, Culture Economics, Correlation Analysis, Clustering } \\
\text { Roadmap, Clustering Strategy, Clustering Economics, Corporate Theory, City } \\
\text { Competitiveness, Clustering Approach, Cluster Map, Crisis, Crisis } \\
\text { Management, Clustering Potential, Cluster Strategy Plan, Cluster Management, } \\
\text { cognitive communities, Change, Cooperation and Trust, Communication, } \\
\text { Company Performance, Contestability, Concentration }\end{array}$ & 1 \\
\hline \multirow[b]{3}{*}{$\mathbf{A}$} & Agglomeration Economies & 3 \\
\hline & Agglomeration & 2 \\
\hline & $\begin{array}{l}\text { Ankara, Ahi community, Ahi-order, Ahi community in Ankara, Alanya } \\
\text { Accommodation, Adiyaman, Aggregations, Advantages and Disadvantages Of } \\
\text { Clustering, Advanced Technology Clusters, Ahi community in Ottoman } \\
\text { Shipyards, Automotive Logistics }\end{array}$ & 1 \\
\hline $\mathbf{B}$ & Bucak Marble Sector, Bartın, Bursa, Business Clusters, Brand Value, Brick & 1 \\
\hline \multirow[b]{2}{*}{$\mathbf{D}$} & Diamond Model & 7 \\
\hline & $\begin{array}{l}\text { Destination Competitiveness, Destination Strategies, Denizli Textile Sector, } \\
\text { Differential Impact Section, Development Economics, Defense, Defense } \\
\text { Industry, Defense Industry Clustering, Design Sector }\end{array}$ & 1 \\
\hline \multirow[b]{2}{*}{$\mathbf{E}$} & Economical Geography, Export & 2 \\
\hline & $\begin{array}{l}\text { Erzurum, Erzincan, Economic Growth, e-trade, European Union, Externalities, } \\
\text { External Economies, Empirical Nuclear Physics, Entrepreneurship, } \\
\text { Employment, Endegenous Growth Theory, Export Decision Process, Export } \\
\text { Performance, Excitation Function }\end{array}$ & 1 \\
\hline $\mathbf{F}$ & $\begin{array}{l}\text { Firm Performance Foreign Trade Companies with Share Capital, Flexibility, } \\
\text { Forest Products Industry, Fresh Fruits and Vegetables }\end{array}$ & 1 \\
\hline \multirow{3}{*}{$\mathbf{G}$} & Gaziantep & 3 \\
\hline & Geography & 2 \\
\hline & Global Economic Crises & 1 \\
\hline $\mathbf{H}$ & Health Tourism & 1 \\
\hline \multirow[b]{3}{*}{ I } & Innovation & 11 \\
\hline & Industrial Clusters & 3 \\
\hline & $\begin{array}{l}\text { Internet Banking, İzmir (Manisa) Plastic Sector, İzmir, Isparta Economics, } \\
\text { Information Networks, Information, Isomorphism, Industrial Competitiveness, } \\
\text { Industrial Clustering, Industry Geography, Industry, International Competitive } \\
\text { Power }\end{array}$ & 1 \\
\hline $\mathbf{J}-\mathbf{K}$ & Jewellery Sector, Kayseri Furniture Sector & 1 \\
\hline \multirow{2}{*}{$\mathbf{L}$} & Logistics, Logit Model & 4 \\
\hline & $\begin{array}{l}\text { Logistic Clusters, Logistic Centers, Logistics Sector, Logistic Process, Land } \\
\text { Industry }\end{array}$ & 1 \\
\hline M-N- & Medical Sector, Medical Tourism, Michael Porter, Monte Carlo Simulation, & 1 \\
\hline
\end{tabular}




\begin{tabular}{|c|c|c|}
\hline O-P & $\begin{array}{l}\text { Medical Gadgets and Tools, Manufacturing Costs, NevşehirTourism, } \\
\text { Networks, Network Structure, NUTS Level } 2 \text { Regions, Oxygen Core, } \\
\text { Obstacles, Planning, Policies, Perceived Risk, Place, Proximity }\end{array}$ & \\
\hline \multirow{4}{*}{$\mathbf{R}$} & Regional Development & 6 \\
\hline & Research and Development & 4 \\
\hline & Regional Concentration & 2 \\
\hline & $\begin{array}{l}\text { Rural and Regional Development, Regional Competitiveness, Regional } \\
\text { Policies, Ready-made Clothing, Relationship Level, Resonance }\end{array}$ & 1 \\
\hline \multirow[b]{3}{*}{$\mathbf{S}$} & SME & 3 \\
\hline & Shoe-making Sector, Supply Chain & 2 \\
\hline & $\begin{array}{l}\text { Sectoral Concentration, Sectoral Clustering, Social Capital SWOT Analysis, } \\
\text { Sectoral Foreign Trade Companies, Social Network Analysis, Sales, Sector of } \\
\text { Red Meat Products, Spatial Clustering, Supplier Evaluation Approaches, } \\
\text { Software }\end{array}$ & 1 \\
\hline \multirow{3}{*}{$\mathbf{T}$} & Three star analysis & 3 \\
\hline & Tourism Clustering, Tourism & 2 \\
\hline & $\begin{array}{l}\text { Technocity, Technopark, Top Management, Turkey Manufacturing Industry, } \\
\text { Touristic Product, Tourism Economy, Tourism and Clustering in Turkey, } \\
\text { Textile, Textile Cluster, Tile Model, Tire Location }\end{array}$ & 1 \\
\hline $\mathbf{V}-\mathbf{W}$ & Value Chain, West Mediterranean Region & 1 \\
\hline
\end{tabular}

135 key words utilized in the postgraduate dissertations about clustering within the scope of regional development are demonstrated in Table 8. The word "clustering" is mentioned 27 times in the dissertations. It is followed by the word "cluster" with 12 times, the word "SME" with 3 times and the words "Clustering Policy", "Clustering Supports", "Clustering Analysis", "Clustering Model", "Tile Model" with 2 times respectively. The most mentioned words after the word "clustering" are "Competitive Advantage", "Diamond Model", "Innovation", "Regional Development" and "Competition". The fact that there are many different key words is accepted as an indication that clustering is a subject in many different fields of studies. In Table 9, the distribution of dissertations by their languages, by their research types, the data about average page range of postgraduate dissertations and the distribution of dissertations by academic titles of advisors is are demonstrated.

Table 9: The Distribution of Dissertations by Research Types, Languages, Academic Titles of Advisors and Average Page Range.

\begin{tabular}{|l|c|c|l|c|c|}
\hline \multicolumn{1}{|c|}{ Research Types } & $\boldsymbol{f}$ & $\mathbf{\%}$ & Language & $\boldsymbol{f}$ & $\boldsymbol{\%}$ \\
\hline Qualitative & 18 & 27,27 & Turkish & 59 & 89,39 \\
\hline Quantitative & 46 & 69,70 & English & 7 & 10,61 \\
\hline Unspecified & 2 & 3,03 & Total & $\mathbf{6 6}$ & $\mathbf{1 0 0 , 0 0}$ \\
\hline Total & $\mathbf{6 6}$ & $\mathbf{1 0 0 , 0 0}$ & Page Range & $\boldsymbol{f}$ & $\mathbf{\%}$ \\
\hline Academic Titles & $\boldsymbol{f}$ & $\mathbf{\%}$ & $1-200$ & 34 & 51,52 \\
\hline Professor Doctor & 37 & 56,06 & $201-300$ & 22 & 33,33 \\
\hline Associate Professor & 18 & 27,27 & $301-400$ & 7 & 10,61 \\
\hline Assistant Professor & 11 & 16,67 & $401-500$ & 3 & 4,55 \\
\hline Total & $\mathbf{6 6}$ & $\mathbf{1 0 0 , 0 0}$ & Total & $\mathbf{6 6}$ & $\mathbf{1 0 0 , 0 0}$ \\
\hline
\end{tabular}

As demonstrated in Table 9, it has been determined that $69,70 \%$ of the dissertations about clustering within the scope of regional development were analyzed by quantitative methods while $27,27 \%$ of those were analyzed by qualitative methods; however, research methods of 
two dissertations couldn't be specified. It can be stated under the illumination of the abovementioned data that most of the dissertations about clustering within the scope of regional developments were mostly analyzed by qualitative methods. Also, it has been determined that most of the postgraduate dissertations about clustering within the scope of regional development were written in Turkish $(89,39 \%)$.

According to Table 9, it has been concluded that 66 postgraduate dissertations were written in the average range of 1-200 pages $(51,52 \%)$. It is followed by 22 dissertations with the average range of 201-300 pages (33,33\%), 7 dissertations with the average range of 301400 pages $(10,61 \%)$, and 3 dissertations with the average range of $401-500$ pages $(4,55 \%)$ respectively. It has been determined that $56,06 \%$ of dissertations were conducted by Professor Doctors. It is followed by the Associate Professors (27,27\%) and Assistant Professors $(16,67 \%)$ respectively.

\section{Conclusion, Implications and Limitations}

In this study, the 66 postgraduate dissertations about clustering in terms of regional development published between the years 2006-2017 according to the data base of Council of Higher Education have been evaluated through several parameters. In conclusion, it is possible to state that there has been an increasing interest in clustering in postgraduate dissertations published in 2013 and later. The most dissertations about clustering within the scope of regional development were written in the department of Business Management; furthermore, it is determined that the dissertations are about business management, economy, rural and urban planning, tourism, geography and finance. The most key words mentioned in these dissertations are the words "clustering" and "cluster". Analyzing the academic titles of the authors, the most dissertations were carried out by the Professors. It is followed by Associate Professors and Assistant Professors respectively.

In consequence of the study, it has been concluded that the number of $\mathrm{PhD}$ dissertations about clustering within the scope of regional development is more than that of master ones. When considered the contributions of academic researches and studies by different sectors, the subject of clustering within the scope of regional development should be more dwelt on. In this sense, it can be stated that both quantitative and qualitative studies about clustering in different sectors should be carried out. Another of the results of the study is that the most postgraduate dissertations about clustering were written in the Institute of Social Sciences; however, studies about clustering within the scope of regional development vary in both subject and department in which they are written. For this reason, it can be stated that the subject of clustering arouses interest of academicians from different departments and it is a subject which can be studied by many different disciplines; nonetheless, it can be concluded that the subject of cluster is studied especially in the departments of business management, economy, rural and urban planning and tourism management.

One of the postgraduate dissertation about clustering is entitled "The Urban Tourism: The Tourism Clustering in Historical Peninsula", which was written by Bora (2006). It concludes that there is lack of government policies related to clustering although it is observed that there are cooperation attempts of cluster companies. The study emphasizes that the tourism clustering of the Historical Peninsula is in the developing process with their many partner performing many common activities. In the study conducted by Güneş (2009), the tourism profile and tourism cluster potential of the province of Erzurum was analyzed and evaluated within the scope of the cluster approach. When the tourism cluster potential in Erzurum is examined; it is observed that public institutions and organizations are not sufficiently effective in cluster formation. It has been determined in the research that the sector representatives participating in the research perform a medium level performance in dialogue and communication with public institutions and organizations, in the cooperation between firms, and in relations with suppliers. In cooperation with other tourism companies in the 
sector; they have a low level of performance. Although the tourism sector clustering in Erzurum has met certain criteria, it is stated that it is difficult to talk about a strong and functioning cluster formation in the city.

Kartal (2013) in his research studies the tourism clusters between the years 2000-2012. It is determined with the research that, the studies are limited on tourism cluster in Turkey, and the majority of these studies are still some ongoing projects. The current data in the study shows that tourism cluster can be effective in achieving regional development. The study reveals that more studies are needed on the tourism cluster and that the ongoing project studies should be implemented. Göçen (2013) examined the hotels in Antalya Belek and Kundu regions and the enterprises supplying products to these hotels in various fields, and the relations between them. Thanks to the cluster maps, it was seen that the former suppliers were working with more hotels. It is also observed that the supplier companies working with a large number of hotels provide supply for both regions, while others remain mostly in one region rather than more. Mirza (2015) conducted a research on health tourism cluster in Izmir. University hospitals, private hospitals and clinics serving in the health sector of İzmir have prepared a cluster model in the field of medical tourism, a type of tourism where qualified young labor force and tourism supply are combined. Y1lmaz (2017) analyzed the current situation of tourism cluster in the context of sectoral clustering of Nevşehir. In this study, information about tourism types and tourism stakeholders in Nevşehir province were given. As a result of the analysis, it is indicated that the weaknesses and threats of tourism cluster of Nevşehir province were higher while the strengths and opportunities were less.

The last published postgraduate dissertation about clustering is entitled "Regional Competitiveness and Clustering: Alanya Tourism Accommodation Sector Cluster Analyses and Strategy Proposal", which was written 2017. Sayın (2017) has analyzed Alanya in terms of regional competitiveness and it has concluded that companies have difficulties to reach new markets and new clients; most products come from Antalya to Alanya and this causes a loss of time and money; companies have difficulties to find specialized brainpower for innovation and technological development; there are communicational problems among companies this leads to lack of social capital in the sector; financial resources are inadequate for common projects to improve relationships of companies. The study emphasizes that there is a cluster attempt with very low profile in Alanya and recommends that a cluster management should be constituted and led by the top public institution. Their first action to take needs to apply to national and international funding appeals and prepare tourism projects.

Whereas there are several studies analyzing clustering approach in terms of different aspects, there is not such a bibliometric study about clustering within the scope of regional development; therefore, this study is believed to meet the deficiency in the related literature. On the other hand, researchers can carry out a comparative analysis by analyzing similar subjects and fields for further studies. They can also have comparative analysis with the postgraduate dissertations in different countries in terms of content and structure. Just as every study does have limitations, as this one, as well. The study contains only the postgraduate dissertations about clustering within the scope of regional development which have been published in the last 11 years. In the study, the data base belonging to the Council of Higher Education was utilized, therefore it is possible that there may be dissertations whose data have not been published in the database yet or which have been published in the last 11 years but could not be assessed in this study.

\section{References}

Albekov, A. U., Andreeva, E. U., Vanushkina, V. V. \& Pilivanova, E. K. (2017). The Regional Cluster Initiatives. European Research Studies, Vol. 20(1), pp.234-245.

Amin, A. \& Thrift, N. (2002). Cities: Reimagining The Urban. Cambridge: Polity Press. 
Bathelt, H., Malmberg, A., \& Maskell P. (2004). Clusters and Knowledge: Local Buzz, Global Pipelines and The Process of Knowledge Creation. Progress in Human Geography, Vol. 28(1), pp.31-56.

Bora, G. (2006). Kentsel Turizm: İstanbul Tarihi Yarımada'da Turizm Kümelenmesi. Unpublished Master Thesis. Mimar Sinan Güzel Sanatlar University, İstanbul.

Ceglie, G. \& Dini, M. (1999). SME Cluster and Network Development in Developing Countries: The Experience of UNIDO. Vienna: United Nations Industrial Development Organization.

Çeken, H. (2008). Turizmin Bölgesel Kalkinmaya Etkisi Üzerine Teorik Bir inceleme. Afyon Kocatepe Üniversitesi İktisadi ve İdari Bilimler Fakültesi Dergisi, Vol. 10(2), pp.293306.

Delgado, M., Porter, M. E. \& Stern, S. (2016). Defining Clusters of Related Industries. Journal of Economic Geography, Vol. 16(1), pp.1-38.

Eisingerich, A. B., Bell, S. J., \& Tracey, P. (2010). How Can Clusters Sustain Performance? The Role of Network Strength, Network Openness, And Environmental Uncertainty. Research Policy, Vol. 39(2), pp.239-253.

Enright, M. J. \& Roberts, B. H. (2001). Regional Clustering in Australia. Australian Journal of Management, Vol. 26(1), pp.65-85.

Glaenzer, W. (2018). Bibliometric as A Research Field a Course On Theory and Application of Bibliometric Indicators. http://nsdl.niscair.res.in/jspui/bitstream/123456789/968/1/Bib_Module_KUL.pdf, Accessed: 12.01.2019.

Glinskiy, V., Serga, L., Chemezova, E. \& Zaykov, K. (2016). Clusterization Economy As A Way To Build Sustainable Development Of The Region. Procedia CIRP, Vol. 40, pp.324-328.

Göçen, S. (2013). Turizm Sektöründe Kümelenmenin Rekabetçi Avantaj Açısından Katkılarının Belirlenmesi: Antalya Turizm Bölgesi Örneği. Unpublished Doctorate Thesis. Süleyman Demirel University, Isparta.

Gökkaya, S., Acar, A. \& Yıldırım, M. (2017). Ekoturizm Konusunun Lissansüstü Tezlerde Bibliyometrik Profili. Sosyal Bilimler Enstitüsü Dergisi, Vol. 3, pp.122-130.

Güneş, E. (2009). Turizm Kümelenmesi ve Erzurum Bölgesi Turizm Kümelenme Potansiyeline Yönelik Bir Araştırma. Unpublished Master Thesis. Sakarya University, Sakarya.

Huggins, R. (2008). The Evolution Of Knowledge Clusters: Progress And Policy. Economic Development Quarterly, Vol. 22(4), pp.277-289.

Iordache, C., Ciochină, I. \& Asandei, M. (2010). Clusters-Tourism Activity Increase Competitiveness Support. Theoretical and Applied Economics, Vol. 5(546), pp.99112.

Isbasoiu, G. M. (2006). Industrial Clusters and Regional Development: The Case of Timisoara and Montebelluna. available at: http://mpra.ub.uni-muenchen.de/5037, Accessed: 12.01.2019.

Jacobs, D. (2010). Demystification of Bibliometric, Scientometrics, Informetrics and Webometrics. Dept. of Information Studies. Richardsbay: University of Zululand.

Kachniewska, M. (2013). Towards The Definition of a Tourism Cluster. Journal of Entrepreneurship, Management and Innovation, Vol. 9(1), pp.33-56.

Kartal, G. (2013). Bölgesel Kalkınmada Kümelenme: Türkiye'de Turizm Kümelenmesi (2000-2012). Unpublished Master Thesis. Niğde University, Niğde.

Ketels, C. \& Memedovic, O. (2008). From Clusters to Cluster Based Economic Development. International Journal Technological Learning, Innovation and Development, Vol. 1(3), pp.375-392. 
Ketels, C. (2009). Clusters, Cluster Policy, and Swedish Competitiveness in The Global Economy. Stockholm: Globalization Council.

Koehler, W. (2001). Information Science as "Little Science": The Implication of a Bibliometric Analysis of the Journal of the American Society for Information Science. Scientometrics, Vol. 51(1), pp.117-132.

Lagendijk, A. \& Charles, D. (1999). Clustering as a New Growth Strategy for Regional Economies? A Discussion of New Forms of Regional Industrial Policy in The United Kingdom. Boosting Innovation, The Cluster Approach. Organization for Economic Cooperation and Development, pp.127-153.

Manuela, T. \& Kristina, R. (2017). Towards Competitive Regional Development Through Clusters: Approaches To Their Performance Evaluation. Journal of Competitiveness, Vol. 9(4), pp.133-147.

Massey, D. (1995). Spatial Divisions of Labour: Social Structures and The Geography of Production. Macmillan International Higher Education.

Matopoulos, A., Vlachopoulou, M. \& Manthou, V. (2005). Exploring Clusters and Their Value as Types of Business Networks in The Agricultural Sector. Operational Research, Vol. 5(1), pp.9-19.

Mirza, N. (2015). Turistik Ürüne Dayalı Destinasyon Planlaması: İzmir İli Sağlık Turizmi Kümelenmesi. Unpublished Doctorate Thesis. Dokuz Eylül University, İzmir.

Njøs, R. \& Jakobsen, S. E. (2016). Cluster Policy and Regional Development: Scale, Scope and Renewal. Regional Studies, Regional Science, Vol. 3(1), pp.146-169.

Oerlemans, L. A., Meeus, M. T. \& Boekema, F. W. (2001). Firm Clustering and Innovation: Determinants and Effects. Papers in Regional Science, Vol. 80(3), pp.337-356.

Özyücel, M. (2008), Avrupa Birliği Uyum Sürecinde Türkiye'de Uygulanan Bölgesel Kalkınma Politikaları, Unpublished Master Thesis. Süleyman Demirel University, Isparta.

Porter, M. (1998). On Competition, Boston. Harvard Business Review Books.

Rinia, E., Leeuwen, T. N., Vuren, H. V. \& Raan, A. V. (1998). Comparative Analysis of a Set of Bibliometric Indicators and Central Peer Review Criteria Evaluation of Condensed Matter Physics in The Netherland. Research Policy, Vol. 27(1998), pp.95-107.

Rosenfeld S. A. (1997). Bringing Business Clusters into the Mainstream of Economic Development, European Planning Studies, Vol. 5(1), pp.3-23.

Sayın, M. (2017). Bölgesel Rekabetçilik ve Kümelenme: Alanya Turizm Konaklama Sektörü Küme Analizleri ve Stratejisi Önerisi. Unpublished Doctorate Thesis. Süleyman Demirel University, Isparta.

Scheer, G. \& Zallinger, L. V. (2007). Cluster Management-A Practical Guide, Part A: Overview.

tez.yok.gov.tr, (2019). https://tez.yok.gov.tr/UlusalTezMerkezi/jsp, Accessed: 09.01.2019.

Yılmaz, T. (2017). Sektörel Kümelenme Bağlamında Turizm Kümelenmesi: Nevşehir Üzerine Bir Durum Değerlendirmesi. Unpublished Master Thesis Nevşehir Hac1 Bektaş Veli University, Nevşehir.

Zan, B. U. (2018). Türkiye'de Bilim Dallarında Karşılaştırmalı Bibliyometrik Analiz Çalışması. Türkiye Bilgi ve Belge Yönetimi Bölümleri Lisansüstü Tez Arşivi: http://bbytezarsivi.hacettepe.edu.tr/xmlui/bitstream/handle/2062/202/744.pdf?sequenc e=1, Accessed: 09.01.2019

Zedgenizova, I. \& Ignatyeva, I. (2017). The Problems of Creation and the Prospects for Development of Regional Clusters. European Research Studies Journal, Vol. 20(4A), pp.578-595. 


\section{Author Biography}

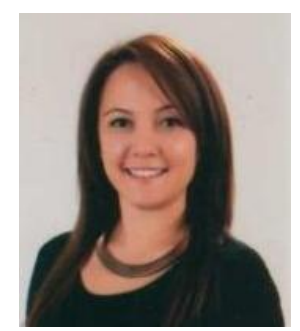

Gencay Saatc1 is currently an Assistant Professor in Tourism Faculty, Çanakkale Onsekiz Mart University, Turkey. She has worked as a lecturer for five years in Uludağ University. She is a holder of a Masters and Ph.D in Hospitality and Tourism Management from Balıkesir University. Her Ph.D. focused on the crosscultural tourist attitudes. Her research interests are tourism sociology, gastronomy tourism and menu management.

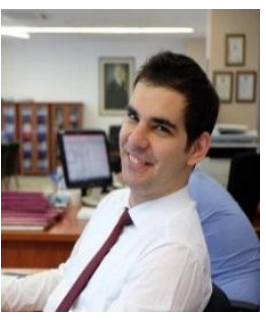

Tarık Yalçınkaya is a Master student at Çanakkale Onsekiz Mart University, Tourism Management Programme. He has several international conference papers and refereed articles about tourism. 